\title{
BANTUAN HUKUM ONLINE NON LITIGASI DALAM RANGKA MENUJU DESA YANG MODERN DAN BERKEADILAN
}

\author{
Suherman ${ }^{1}$, Andriyanto A Nugroho ${ }^{2}$, Yuliana Yuli ${ }^{3}$, Wahyo $\mathrm{S}^{4}$, Human Santoso ${ }^{5}$ \\ ${ }^{1,2,3}$ Fakultas Hukum, Universitas Pembangunan Nasional Veteran Jakarta \\ ${ }^{4}$ Universitas Pembangunan Nasional Veteran Jawa Timur \\ ${ }^{5}$ Universitas Pembangunan Nasional Veteran Yogyakarta
}

Email: suherman@upnvj.ac.id

\begin{abstract}
Most of the peoples of Baros village work in the agricultural and plantation sectors with most of the peoples having education up to junior high and high school levels. Thus, they do not understand the law and technology that is currently developing due to their low educational background. Therefore, Baros Village needs socialization about the online legal assistance of nonlitigation in order towards a modern and justice village. The method used is in the form of socialization accompanied by counseling to the community, namely by providing explanations and discussions with the aim of activities that Baros villagers understand the importance of online legal assistance through non-litigation using current technology such as computers, laptops and hand phones. The results of the activities in the socialization turned out to be many Baros villagers who did not understand the existence of online legal assistance to resolve their cases outside the court such as negotiation, mediation, conciliation, and consultation. The village office must provide an internet network, computer or laptop for its citizens to learn technology in order to become a modern village.
\end{abstract}

Keywords: modern and justice; non-litigation; Online legal assistance

\begin{abstract}
Abstrak
Sebagian besar penduduk desa Baros bekerja di sektor pertanian dan perkebunan dengan sebagian besar warganya mempunyai pendidikan sampai tingkat SMP dan SMA. Sehingga mereka kurang memahami hukum dan teknologi yang berkembang saat ini dikarenakan latar belakang pendidikan yang masih rendah. Oleh karenanya, Desa Baros perlu adanya sosialisasi tentang pentingnya memahami teknologi dan hukum untuk dapat menyelesaikan sengketanya secara online dan melalui alternative penyelesaian sengketa diluar pengadilan atau non litigasi. Metode yang digunakan berupa sosialisasi disertai penyuluhan kepada masyarakat yaitu dengan memberikan penjelasan dan diskusi dengan tujuan kegiatan agar warga desa Baros memahami pentingnya bantuan hukum online melalui non litigasi dengan menggunakan teknologi saat ini seperti komputer, laptop dan Hand phone. Hasil kegiatan dalam sosialisasi ternyata banyak warga desa Baros yang tidak memahami adanya bantuan hukum online untuk menyelesaikan perkaranya melalui diluar pengadilan seperti negosiasi, mediasi, konsiliasi, konsultasi. Kantor desa harus menyediakan jaringan internet, komputer atau laptop untuk warganya belajar teknologi agar menjadi desa yang modern.
\end{abstract}

Kata Kunci : Modern dan berkeadilan; non litigasi; bantuan hukum online

\section{PENDAHULUAN}

\section{Analisis Situasi \\ Wilayah Desa Baros yang berada di Kecamatan Baros , Kabupaten Serang}

yang jaraknya $137 \mathrm{KM}$ dari Jakarta.

Desa Baros merupakan daerah yang terletak didataran, pada ketinggian 1600 meter dari permukaan laut. Desa Baros 
letaknya berbatasan dengan Desa Kemanisan disebelah utara, Desa Sukamanah disebelah selatan, Desa Curug Agung disebelah Timur. Luas Desa Baros adalah $282 \mathrm{Ha}$, dengan jumlah penduduk laki-laki 3427 dan penduduk perempuan sebesar 3130, Jadi jumlah penduduk Desa Baros sebesar 6557 Penduduk dengan jumlah Kepala Keluarga 1980 KK. Di Desa Baros warga yang lulusan sarjana 175 orang, lulus SLTA 1440 orang, Lulus SLTP 1350 orang, Lulus SD 350 orang dan tidak menyelesaikan Pendidikan 290 orang. Sehingga di desa Baros Sebagian besar penduduknya berpendidikan SMP dan SMA, dan sebagian besar penduduknya bekerja sebagai karyawan/ABRI/PNS 400 orang, wiraswasta/pedagang 315 orang, Bertani 705 orang, Pertukangan 26 orang, Pensiunan 10 orang, Jasa 75 orang dan lain-lain. (Profil Desa Baros, 2020 : 1-2).

Di wilayah Desa Baros Kecamatan Baros, Kabupaten Serang merupakan wilayah yang kurang memahami hukum dan teknologi dikarenakan latar belakang pendidikan yang Sebagian besar lulusan SMP dan SMA. Sehingga atas ketidakpahaman warga masyarakat desa Baros ini mereka harus mendapat pendampingan tentang bagaimana untuk menyelesaikan sengketa hukum atau bagaimana melindungi haknya secara hukum melalui bantuan hukum online agar mereka mendapatkan perlindungan hukum dan keadilan.

Pendidikan warga yang masih rendah ini juga yang menyebabkan banyaknya warga desa Baros menyelesaikan masalah hukumnya dengan cara main hakim sendiri atau mereka langsung ke kepolisian untuk masalah pidananya atau kepengadilan untuk masalah perdata umum dan keluarga. Mereka tidak mengatahui adanya penyelesaian sengketa diluar pengadilan atau non litigasi yang dapat mereka tempuh seperti konsultasi, negosiasi, mediasi, konsiliasi dan arbitrase. Oleh karenanya, mereka perlu di informasikan dan disosialisasikan melalui pengabdian masyarakat tentang bantuan hukum online nonlitigasi dalam rangka menuju masyarakat desa yang modern dan berkeadilan.

Pada saat ini dengan kemajuan teknologi, maka disemua bidang kehidupan juga telah menyesuaikan dengan menggunakan teknologi yang modern, seperti dibidang jasa, bidang produksi produk makanan, bidang Pendidikan termasuk dibidang penegakkan hukum. Di bidang jasa advokat dan Lembaga Bantuan Hukum (LBH) juga telah menngunakan teknologi dalam memberikan bantuan hukum kepada warga masyarakat seperti pelayanan hukum online dan penyelesaian sengketa diluar pengadilan atau nonlitigasi online. Pelayanan bantuan hukum online ini dapat dilakukan dengan melalui telepon, maupun lewat chat WhatsApp, melalui pertemuan lewat zoom cloud meeting, Google meet atau teknologi yang lainnya untuk konsultasi yang terkait dengan berbagai perkara hukum seperti kasus pidana / kriminal, perdata, hutangpiutang, penyalahgunaan narkoba, sengketa waris, perkawinan, pengesahan nikah siri, perceraian, kekerasan dalam 
rumah tangga (KDRT), adopsi anak, dan lain-lain.

Konsultasi Hukum Online lewat chat WhatsApp adalah layanan konsultasi hukum yang sangat mudah dan sederhana melalui sarana media sosial Wahts App atau yang lebih dikenal dengan WA bagi warga yang mempunyai masalah hukum yang berhubungan dengan kasus sehari-hari. Oleh karenanya, konsep bantuan hukum secara konvensional tradisional telah banyak di tinggalkan oleh klien, karena pada konsep ini sifat bantuan hukumnya bersifat pasif dalam arti bahwa para penesehat hukum hanya menunggu masyarakat atau klien untuk datang ke kantornya untuk meminta bantuan hukum dan mengadukan permasalahannya, Tapi pada saat ini advokat dan kantor hukum bisa menggunakan aplikasi WhatsApp (WA), facebok, instagram untuk memperkenalkan dirinya dan kantor hukumnya dalam memberikan bantuan hukum pada perusahaan-perusahan dan orang pribadi (Bambang Sutiyoso dan Sri Hastuti Puspitasari, 2005 ; 9). Bantuan hukum secara online dapat dilakukan bukan hanya secara individu saja, tapi juga dapat dilakukan secara kelompok. Juga dalam melakukan bantuan hukum secara online bukan hanya untuk perkara yang terkait dengan litigasi saja tapi bisa juga digunakan untuk menyelesaikan perkara melalui jalur non litigasi seperti dengan negosiasi, mediasi, konsiliasi dan arbitrase.

Konsep bantuan hukum online lahir sebagai konsekuensi dari kemajuan teknologi misalnya, dengan internet maka seolah-oleh sudah tidak ada lagi batas antara jarak, ruang dan waktu diantara negara di dunia ini. Sehinga kemajuan teknologi yang modern tersebut juga mempengaruhi dalam pemberian bantuan hukum kepada masyarakat. Hukum juga sebenarnya merupakan superstruktur yang selalu berubah dan merupakan hasil interaksi antar infrastruktur yang ada dalam masyarakat. Oleh karena itu, selama pola hubungan antar infrastruktur menunjukan gejala yang timpang maka hal tersebut akan mempersulit terwujudnya hukum yang adil (Adnan Buyung Nasution:1981). Konsep bantuan hukum online ditujukan bukan hanya bagi masyarakat dengan ekonomi yang cukup dan yang memahami hukum, tetapi juga dapat menjangkau kepada masyarakat miskin yang buta hukum dan tidak mampu secara ekonomi. Karena Negara menjamin di dalam Konstitusi kita setiap warga negara mempunyai kedudukan yang sama di muka hukum dan semua negara berhak untuk mendapatkan bantuan hukum secara maximal (Bambang Sutiyoso dan Sri Hastuti Puspitasari, 2005;9). Negara juga menjamin hak asasi setiap warganegaranya sehingga setiap orang akan mendapatkan perlindungan hukum yang sama dan mendapatkan kepastian hukum (Bachtiar, 2016 ; 137).

Berdasarkan hal diatas, maka mendapatkan bantuan hukum baik secara konvensional atau secara online merupakan hak asasi yang dimiliki oleh setiap orang. (Satya Arinanto, $2015 ; 72$ ) . Begitu juga bagi warga desa Baros 
mempunyai hak yang sama untuk mendapatkan bantuan hukum secara online untuk perkara non litigasi yang dihadapinya sehingga perlu adanya sosialisasi dan pendampingan bantuan hukum tersebut yang bertujuan untuk memberikan keadilan yang sama bagi masyarakat yang sedang menghadapi masalah hukum sehingga akan lebih cepat mengerti dan memahami langkahlangkah hukum yang diambil untuk menyelesaikan masalah hukumnya melalui non litigasi.

\section{Permasalahan}

Apakah warga Desa Baros mengetahui dan memahami tentang bantuan hukum on line nonlitigasi agar menjadi desa yang modern dan berkeadilan. Dalam pengabdian ini mitra sasarannya adalah kepala desa dan aparat desa Baros juga bagi warga desa yang sedang mempunyai sengketa atau permasalahan hukum dengan pihak lain atau warga desa yang tidak memiliki permasalahan hukum di Desa Baros.

\section{TINJAUAN LITERATUR}

\section{Bantuan Hukum Online}

Negara mempunyai kewajiban dan menjamin untuk memberikan kepastian hukum dan perlindungan hukum bagi setiap warganegaranya dihadapan hukum, sebagaimana tertuang dalam konstitusi UUD 1945. Karenanya, hal ini diatur lebih lanjut dalam Undangundang No. 16 Tahun 2011 tentang Bantuan Hukum. Di dalam Undangundang ini disampaikan divinisi dari bantuan hukum adalah jasa hukum yang diberikan secara Cuma-Cuma oleh pemberi bantuan hukum kepada penerima bantuan hukum.

Tujuan dari bantuan hukum yang diberikan oleh negara kepada masyarakat yang kurang mampu agar mereka juga mendapatkan keadilan di muka hukum dan menjamin kepastian hukum. Penerima bantuan hukum adalah orang atau sekelompok orang bagi mereka yang kurang mampu yang mendapatkan bantuan dari kantor-kantor bantuan hukum yang ditunjuk oleh pengadilan untuk membentu mereka di Pengadilan atau bisa juga diluar pengadilan melalui negosiasi dan mediasi. Sedangkan bagi warga masyarakat yang mampu mereka bisa mencari dan meminta bantuan hukum pada kantor-kantor hukum yang mereka tunjuk sendiri untuk mendampingi mereka di Pengadilan.

Kemajuan teknologi saat ini, sehingga pemberi bantuan hukum juga banyak memberikan bantuan hukumnya menggunakan perangkat teknologi yang berkembang saat ini seperti menggunakan zoom cloud meeting. Google meet, WhatsApp, Telegram, dan lainnya secara online. Bantuan hukum online adalah bantuan hukum yang diberikan oleh pemberi bantuan hukum kepada penerima bantuan hukum dengan menggunakan perangkat teknologi seperti WhatsApp, telpon dan yg lainnya dari setiap masalah hukum yang dihadapi oleh penerima bantuan hukum.

\section{Non Litigasi}

Dalam pergaulan hidup masyarakat terkadang timbul suatu perbedaan pendapat atau timbul adanya 
pihak yang merasa dirugikan yang akhirnya menimbulkan sengketa diantara para pihak. Sengketa adalah adanya perbedaan kepentingan antara individu atau badan hukum yang satu dengan yang lainnya terhadap suatu obyek yang sama yang dimanifestasikan dalam hubungan diantara mereka. Sedangkan konflik hukum adalah arising in the case of persons who have acquire rights or incurred obligations or made contracts, maksudnya sengketa adalah suatu kasus dari orang-orang yang telah memperoleh hak atau menimbulkan kewajiban atau membuat kontrak. (Henry Campbell Black, 1990 : 299).

Sengketa yang terjadi antara orang atau badan hukum dengan yang lainnya ini dapat diselesaukan melalui jalur litigasi dan jalur non litigasi. Jalur litigasi adalah penyelesaian sengketa melalui proses di pengadilan sedangakan jalur non litigasi adalah penyelesaian sengketa diluar pengadilan yang sering di sebut dengan alternative penyelesaian sengketa atau alternative dispute resolution $(A D R)$. Ada beberapa ADR yang dikenal dalam penyelesaian sengketa non litigasi ini seperti konsultasi, negosiasi, mediasi dan konsiliasi serta arbitrase.

Konsultasi adalah act of consulting or conferring, example : client with lawyer and deliberation of persons on some subject, yaitu tindakan konsultasi atau berunding, contoh: klien dengan pengacara dan pertimbangan orangorang tentang beberapa hal.Setelah konsultasi maka para pihak yang bersengketa dapat menyelesaikan masalahnya dengan jalan negosiasi yaitu to communicate or confer with another so as to arrive at the settlement of some matter adalah untuk berkomunikasi atau berunding dengan yang lain sehingga sampai pada penyelesaian beberapa masalah. Negosiasi ini biasanya dilakuka oleh para pihak yang bersengketa tidak ada pihak ketiga. (Henry Campbell Black, 1990 : 1035).

Apabila negosiasi tidak tercapai, maka akan dilakukan penyelesaian sengketa dengan bantuan pihak ketiga yang disebut dengan mediasi, konsiliasi dan arbitrase. Mediasi adalah private, informal dispute resolution process in which a neutral third person as the mediator, yaitu pribadi, proses penyelesaian sengketa informal di mana orang ketiga yang netral sebagai mediator. Konsiliasi adalah the adjustment and settlement of a dispute in a friendly, unantagonistic manner thorugh third party as neutral person, maksudnya penyesuaian dan penyelesaian sengketa dengan cara yang bersahabat dan tidak bermusuhan dengan dibantu oleh pihak ketiga yang netral (konsiliator). Sedangkan arbitrase adalah a process of dispute resolution in which a neutral third party (arbitrator) renders decision after a hearing at which both parties have an opportunity to be heard, yaitu proses penyelesaian sengketa di mana pihak ketiga yang netral (arbiter) membuat keputusan setelah sidang di mana kedua belah pihak memiliki kesempatan untuk didengar. (Henry Campbell Black, 1990 : 105). 


\section{Modern dan Adil}

Modern adalah sikap dan cara berpikir serta cara bertindak sesuai dengan tuntutan zaman. Sedangkan menurut Kamus Besar Bahasa Indonesia (KBBI), arti kata modern adalah terbaru. Arti lainnya dari modern adalah mutakhir. Kata modern berasal dari bahasa Inggris. Dalam tinjauan kamus Longman Dictionary of Contemporary English disebutkan bahwa kata "modern" adalah bentuk adjective atau kata sifat modern adj; of the present time, or of the not far distant past; not ancient. Berarti modern itu menunjukkan sifat sesuatu yang baru yang berlaku pada masa kini, atau masa yang tidak terlalu jauh dari masa kini, atau tidak kuno.

Sedangkan Adil menurut Kamus Besar Bahasa Indonesia (KBBI) online adalah sama berat, tidak berat sebelah, tidak memihak, berpihak pada yang benar dan tidak sewenang-wenang. Sementara Keadilan diartikan sebagai suatu sifat atau perbuatan atau perlakuan yang adil. (Darji D dan Shidarta, 1995 : 156), Keadilan berasal dari kata adil dalam Bahasa Inggris disebut "Justice", yang berarti jujur (honest), benar (right) dan menurut hukum (legal right), pantas (fair), layak (righteous). (Munir Fuady, $2000: 90)$.

Banyak para ahli yang menyampaikan dalam suatu teori keadilan salah satunya adalah John Rawl, menurut John Rawls ada dua prinsip principle of greatest equal liberty dan the difference principlel the difference principle and the principle of fair equality of opportunity. perbedaan sosial dan ekonomis harus diatur agar memberikan manfaat yang paling besar bagi mereka yang kurang beruntung atau keberpihakan kelompok lemah. (Munir Fuady, 2000 : 90).

\section{METODE PELAKSANAAN}

Metode yang digunakan dalam kegiatan pengabdian kepada masyarakat di Desa Baros ini adalah dengan metode presentasi dan diskusi kepada para warga masyarakat di desa tersebut melalui media sosial baik melalui WhatsApp, Goegle meet, atau Zoom cloud meeting.(Hendri Dhony, Francisca S : 2021, 345) Hal ini terjadi dikarenakan adanya situasi dan kondisi pandemic corona virus atau covid 19 secara global di Indonesia dan di Negara lain, kejadian ini sudah berlangsung kurang lebih satu tahun setengah sejak awal maret 2020 sampai saat ini juni 2021. Sehingga Pemerintah menerapkan yang awalnya Pembatasan Sosial Berskala Besar (PSBB) yang dirubah menjadi Pembatasan Kegiatan Masyarakat Skala Mikro (PPKM) yang berdampak dengan adanya penjagaan yang sangat ketat untuk keluar masuknya orang dalam suatu kampung atau desa.

Supaya pelaksanaan pengabdian masyarakat ini dapat berjalan dengan baik dan mencapai tujuan yang diharapkan, maka dengan kondisi pandemic covid 19 pengabdi melakukan sosialisasi bantuan hukum nonlitigasi ini dengan cara tatap muka online melalui zoom cloud meeting. Tapi masalah dihadapai dalam tatap muka online tersebut karena terbatasnya warga masyarakat yang memiliki lap top atau 
HP Android, maka satu lap top dipakai bersama-sama dengan warga baros dalam pengabdian masyarakat tersebut dan hanya beberapa orang saja yang mengikuti pengabdian ini dengan menggunakan Hp Androidnya.

Warga peserta pengabdian berkumpul di aula desa Bros pada pukul 10.00 Wib kemudian mereka diharuskan mengisi daftar kehadiran warga supaya acara dapat berjalan tertib dan terdata dengan baik. Mereka yang hadir merupakan warga yang telah terdata sebelumnya, Karena pengabdi pada bulan Febuari 2021 telah berkunjung ke kantor desa Baros untuk melakukan wawancara dengan kepala desa dan sekretaris desa untuk mengetahui kondisi warga desanya terkait dengan sengketa yang banyak terjadi disana sebelum pengabdi menanyakan langsung kepada warga yang sendang menghadapi sengketa tersebut yang nantinya akan diundang dalam acara pengabdian masyarakat pada bulan Juni 2021

Metode kegiatan pengabdian masyarakat ini juga dilakukan dengan beberapa tahapan. Adapun tahapan yang dilakukan tim pengabdi adalah sebagai berikut:

\section{a. Dalam Tahap Persiapan}

Pada tahap awal persiapan untuk melakukan pengabdian masyarakat di desa Baros, maka tim pengabdi yang terdiri dari seorang ketua dan dua orang anggota melakukan kunjungan kepada Kepala Desa Baros yang dilaksanakan pada Bulan Febuari 2021. Dalam tahap ini ditujukan agar dapat membangun komunikasi yang aktif dengan kepala desa dan staffnya agar dalam acara pengabdian masyarakat tersebut mendapat izin dan diketahui oleh pejabat setempat. Pada tahap persiapan ke desa Baros juga digunakan untuk menggali sumber-sumber masalah yang ada di masyarakat Baros atau disebut juga pengumpulan data empiris (field research) langsung mengamati jenis sengketa apakah yang dialami oleh masyarakat di desa tersebut. Berdasarkan hasil observasi dan wawancara dengan para warga maka ada beberapa warga yang sedang menghadapi perkara pidana, perkara perdata dan perkara rumah tangga dan hasil wawancara juga banyak warga yang belum mengetahui tentang penyelesaian sengketa diluar pengadilan atau non litigasi dari perkara yang mereka hadapi untuk penyelesaian sengketanya. Selanjutnya tim pengabdi menentukan jumlah peserta yang diundang sebanyak 20 orang yang nantinya akan ikut dalam acara pendampingan dan sosialisasi tersebut.

\section{b. Proses Perijinan}

Dalam proses perizinan ini pengabdi mengurus proses perizinan ini bersamaan dengan proses persiapan pada kunjuangan awal ke kantor desa Baros. Pengabdi mengajukan surat permohonan kerjasama antara pengabdi dengan kepala desa Baros. Surat permohonan pengabdi mendapat surat jawaban yang intinya kepala desa setuju untuk dilaksanakan pengabdian masyarakat di desanya yang selanjutnya di tanda tanganinya surat kesepakatan untuk mengadakan pengabdian masyarakat yang juga telah ditentukan tanggal pelaksanaan pengabdian 
masyarakat yang jatuh pada tanggal 8 Juni 2021.

\section{c. Tahap Pelaksanaan}

Dalam tahap pelaksanaan ini kegiatan pengabdian masyarakat dilakukan secara online karena kondisi covid 19 dan PPKM yang terjadi menyebabkan pengabdian ini tidak bisa dilakukan secara tatap muka langsung. Pelaksanaan pengabdian ini dengan menggunakan zoom cloud meeting yaitu pengabdi memberikan presentasi kepada warga yang dilanjutkan dengan diskusi dan tanya jawab. Banyak warga yang bertanya dan antusias dalam acara tersebut mereka terkait dengan bantuan hukum nonlitigasi secara online. Akan tetapi, karena terbatasnya lap top yang dimiliki oleh masyarakat desa Baros maka dalam pelaksanaannya hanya menggunakan dua laptop saja yang ditonton bersama oleh beberapa warga desa Baros yang hadir dalam pengabdian tersebut dan hanya beberapa orang yang menggunakan HP Android.

\section{d. Pelaporan Hasil Pelaksanaan}

Setelah pelaksanaan, maka tim pengabdi membuat laporan kemajuan yang disampaikan ke institusi pengabdi. Tim membuat laporan tertulis mengenai hasil dari sosialisasi kepada warga Baros tersebut kepada institusi pengabdi yang dilanjutkan dengan membuat artikel jurnal pengabdian yang nantinya akan diterbitkan di jurnal pengabdian masyarakat.

\section{HASIL DAN PEMBAHASAN}

Hasil pengabdian masyarakat yang dilaksanakan secara online ini berjalan lancar dan mencapai tujuan yang ditargetkan yaitu memberikan pemahaman tentang bantuan hukum online dalam penyelesaian sengkata melalui non litigasi agar mencapai masyarakat desa yang modern dan berkeadilan. Sosialisasi yang dilakukan ini juga mengajarkan kepada warga desa Baros untuk bagaimana berkonsultasi dengan menggunakan alat teknologi yang berkembang pada saat ini.

Sosialisasi adalah mentransfer ilmu dengan memberikan materi dari pengabdi kepada warga masyarakat agar dapat dipahami dan dipraktekan langsung. Sosialisasi diarahkan bagi kelangsungan masyarakat, kelompok sosial dan kebudayaan. Sosialisasi kepada masyarakat terkait bantuan hukum online ini menjadi sangat penting, karena Kenyataan banyak warga masyarakat yang belum mengerti hukum dan belum mengetahui bagaimana memperjuangkan haknya di dalam hukum.

Keberadaan masyarakat kelompok ini memerlukan suatu tindakan aktif dari Pemerintah atau Perguruan Tinggi untuk melindungi hak-hak dan kepentingankepentingan mereka dalam hukum melalui sosialisasi hukum dan pendampingan hukum secara nyata. 


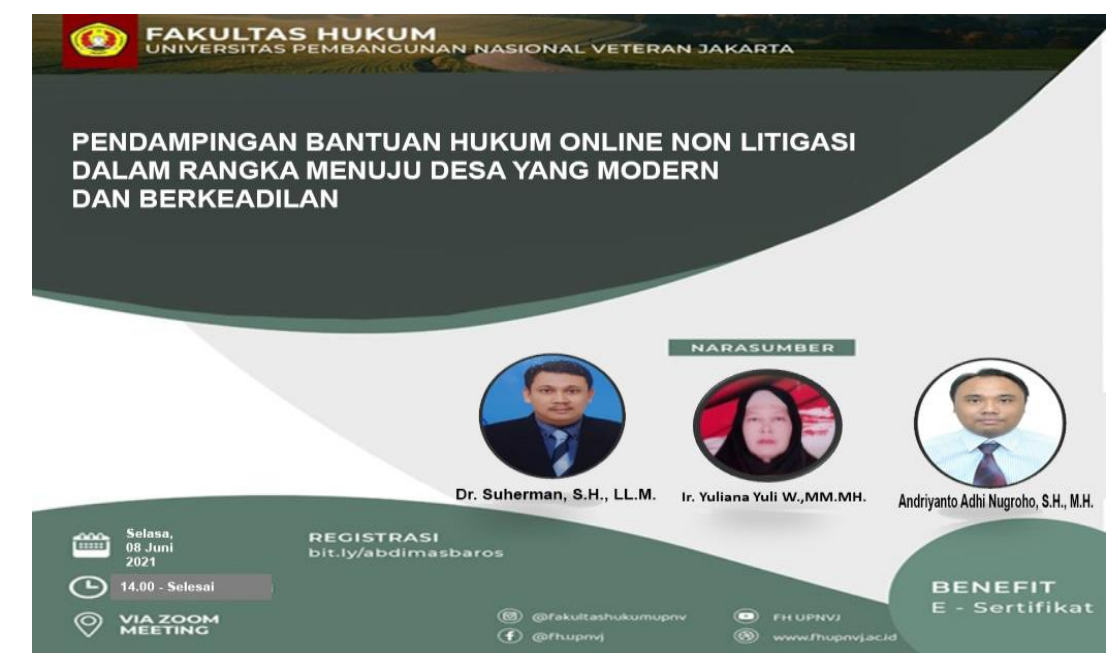

Gambar 1. Poster Pengabdian Kepada Masyarakat

Pendampingan hukum bagi setiap orang adalah merupakan hak dasar yang dimiliki oleh setiap orang yang hal ini diatur dalam konstitusi. Di dalam UU No. 16 Tahun 2011 tentang bantuan hukum diatur tentang adanya bantuan hukum secara Cuma-Cuma yang disediakan oleh negara bagi warga masyarakat yang membutuhkan dalam rangka menjamin kepada setiap warga negara akan akses terhadap keadilan (access to justice). (Suyogi Imam Fauzi dan Puspita Ningtyas, $2018 ; 3)$

Disisi lain, kemajuan teknologi saat ini akan membawa banyak kemudahan dan membuat tidak ada jarak antara yang satu dengan yang lainnya begitu juga halnya dengan praktek hukum saat ini. Bantuan hukum yang diberikan oleh kantor hukum telah juga menggunakan kemajuan teknologi diantaranya dengan Hand Phone (Hp) Android saat ini, maka para advokat dapat menggunakan aplikasi WA untuk memberikan bantuan hukum kepada kliennya.

Advokat mempunyai kewajiban yang mulia untuk membantu setiap orang yang membutuhkan bantuan dibidang hukum officium nobile (Profesi mulia) sebagaimana yang telah diamanatkan dalam UU No. 18 Tahun 2003 tentang Advokat. Para penegak hukum yang lain seperti hakim dan jaksa juga mempunyai kewajiban untuk menegakkan hukum dan memperlakukan setiap warga negara mempunyai kedudukan yang sama di muka hukum termasuk juga masyarakat miskin atau prinsip equality before the law. Menurut Rhode prinsip tersebut juga dimaknai adanya kemudahan aksess terhadap hukum dan keadilan (access to law and justice). ( Deborah L Rhode, 2004 :3)

Berdasarkan prinsip kemudahan akses terhadap hukum dan keadilan tersebut, maka para penegak hukum harus dapat memanfaatkan kemajuan teknologi yang ada saat ini yang dapat memberikan kemudahan bagi warga masyarakat yang mencari keadilan. Misalnya : Hakim, jaksa dan advokat sudah bisa melakukan pemberkasan persidangan online dan sidang online dalam memeriksa perkara baik terhadap perkara pidana, perkara perdata dan perkara keluarga.

Advokat dalam menyelesaikan perkara perdata dan perkara tentang keluarga dari kliennya bisa mengarahkan 
agar perkaranya diselesaikan secara nonlitigasi atau diluar pengadilan sebelum masuk ke Pengadilan. Alternative Dispute Resolution (ADR) atau Alternative Penyelesaian Sengketa diluar pengadilan adalah merupakan salah satu bentuk penyelesaian sengketa berdasarkan kesepakatan dari para pihak yang bersengketa dan sangat berkembang saat ini. Hal ini dikarenakan pertimbangan efisiensi dan keuntungan bagi kedua belah pihak. Perkembangan ADR ini juga karena banyak pihak-pihak yang tidak puas dengan penyelesaian sengketa melalui pengadilan karena waktu lama, biaya lebih mahal dan putusannya ada yang menang dan kalah.

Penyelesaian sengketa diluar pengadilan adalah penyelesaian sengkata yang dilakukan dengan itikad baik dari para pihak. Di dalam Pasal 1 angka $10 \mathrm{UU}$ arbitrase dan APS menentukan "Alternatif Penyelesaian Sengketa adalah lembaga penyelesaian sengketa atau beda pendapat melalui prosedur yang disepakati para pihak, yakni penyelesaian di luar pengadilan dengan cara konsultasi, negosiasi, mediasi, konsiliasi atau penilaian ahli." Jadi secara garis besar penyelesaian sengketa dibagi menjadi dua yaitu melelui jalur litigasi atau Pengadilan Negeri dan melalui jalur non litigadi atau diluar pengadilan.

Pada pengabdian masyarakat ini, tim pengabdi mengambil tema terkait dengan bantuan hukum online non litigasi menuju masyarakat modern dan berkeadilan di desa Baros, Kabupaten Serang. Pada saat pelaksanaan sosialisasi dan pendampingan ini, tim pengabdi mengundang warga desa Baros dan pegawai desa Baros untuk ikut dalam pengabdian masyarakat ini. Dalam pengabdian ini selain memberikan materi tentang bantuan hukum non litigasi juga memperkenalkan warga desa Baros terkait dengan kemajuan teknologi berupa pertemuan atau meeting yang dapat dilakukan dengan cara jarak jauh melalui online dengan menggunakan zoom cloud meeting atau whats Apps (Wa), sehingga tidak harus bertatap muka langsung dalam acara pengabdian ini. Akan tetapi, karena banyak warga desa yang tidak memiliki lap top atau Hp Android, maka dalam pengabdian ini hanya menggunakan dua Lap top saja yang disaksikan bersama-sama warga desa Baros yang hadir dalam acara pengabdian ini. Pengabdi memberikan materinya kepada peserta abdimas terkait dengan:

a. Pengertian alternative penyelesaian sengketa di luar pengadilan adalah merupakan mekanisme penyelesaian sengketa diluar pengadilan dengan mempertimbangkan segala bentuk efisiensiya dan untuk tujuan yang akan datang sekaligus menguntungkan bagi para pihak yang bersengketa dengan didasarkan pada kesepakatan para pihak yang bersengketa. Pengabdi juga menjeleskan tentang bentuk-bentuk dari penyelesaian sengketa diluar pengadilan atau non litigasi kepada para peserta yang terdiri dari konsultasi, negosiasi, mediasi, konsiliasi dan arbitrase.

b. Konsultasi adalah suatu tindakan pribadi sebagai klien dengan pihak konsultan sebagai seorang yang ahli dibidangnya dengan memberikan jawaban atas pertanyaan kliennya. (Andi Ardillah Albar, 2019 ; 22) Dalam konsultasi ini masyarakat sebagai klien pergi ke kantor Bantuan Hukum dan bertemu dengan seorang advokat yang akan membantu untuk 
menjawab semua pertanyaan dari masyarakat yang mempunyai sengketa atau bisa juga pertanyaan disampaikan melalui WA atau sms ke nomor HP dari advokat atau pertemuan melalui zoom cloud meeting atau google meet dengan memanfaatkan kemajuan teknologi saat ini. Tetapi, dalam konsultasi ini keputusan tetap berada di tangan klien.

c. Bentuk yang kedua adalah negoiasi adalah komunikasi yang dilakukan secara dua arah diantara para pihak yang bersengketa yang memiliki kepentingan yang sama untuk mencapai suatu kesepakatan dan dalam negosiasi ini juga tidak melibatkan pihak ketiga dalam menyelesaikan masalahnya tersebut. (Syafrida, 2020 : 357). Jadi masyarakat Baros yang bersengketa antara yang satu dengan yang lainnya bisa diselesaikan diantara para pihak saja dengan tatap muka langsung untuk dapat menyelesaikan sengketa tersebut. Akan tetapi, bisa juga dilakukan melalui pembicaraan dengan HP atau WA / sms. Saran kami sebagai pengabdi sebaiknya dalam tingkat negosiasi ini sebaiknya dilakukan secara tatap muka langsung agar dapat juga langsung saling meminta maaf atau saling memaafkan dan menyelesaikan secara kekeluargaan.

d. Bentuk yang ketiga adalah mediasi adalah penyelesaian sengketa diluar pengadilan dengan bantuan pihak ketiga yang disebut dengan mediator. Peran mediator disana adalah memberikan arahan dan nasehat kepada para pihak untuk tercapainya suatu kesepakatan, tetapi mediator tidak dapat memberikan suatu keputusan dari sengketa para pihak tersebut, karena putusan diserahkan kepada para pihak yang bersengketa. (Fajar Sugianto, etc, 2020 : 3). Jadi, apabila antar warga Baros terjadi sengketa sebenarnya dalam praktek dilapangan warga yang bersengketa itu bisa minta bantuan kepada kepala desa dan perangkatnya untuk menjadi mediator dalam rangka membantu warganya menyelesaikan sengketa tersebut. Jadi, dengan adanya pendampingan dan penyuluhan hukum ini diharapkan baik bagi kepala desa dan perangkatnya dapat memahami dan memprektekan bagaimana bertindak sebagai mediator, sedangkan bagi warga Baros dapat memahami cara penyelesaian sengketa yang sederhana dan cepat.

e. Bentuk yang keempat konsiliasi adalah penyelesaian sengketa diluar pengadilan dengan bantuan pihak ketiga yang disebut dengan konsiliator. Peran konsiliator disana adalah memberikan arahan dan nasehat kepada para pihak untuk tercapainya suatu kesepakatan dan konsiliator dapat memberikan suatu keputusan dari sengketa para pihak tersebut, akan tetapi putusan ini tikdak mengikat para pihak. Jadi, berdasarkan kemauan dan kesadaran para pihak saja apakah putusan tersebut akan dilaksanakan atau tidak dilaksanakan.

Dalam penyelesaian sengketa melalui konsiliasi ini, maka biasanya yang dapat menjadi konsiliator adalah pegawai dari institusi 
Pemerintah yang telah mengikuti pelatihan ADR khusnya tentang konsiliasi, contohnya terhadap kasuskasus hubungan kerja antara pekerja dengan perusahaan ditempatnya bekerja yang dapat diselesaikan melalui konsiliasi di Kantor Dinas Ketenagakerjaan di wilayah domisili perusahaan tersebut. (Nevey Varida Ariani, 2012: 283).

f. Bentuk yang kelima arbitrase adalah penyelesaian sengketa diluar pengadilan melalui satu atau tiga orang arbiter (Biasanya jumlah ganjil) yang ditentukan oleh para pihak yang bersengketa. Dalam penyelesaian sengketa melalui arbitrase ini para pihak harus membuat perjanjian tertulis yang menyatakan mereka setuju untuk perkaranya diselesaikan melalui arbitrase. Jadi, untuk dapat diselesaikan melalui mekanisme arbitrase, dibutuhkan kesepakatan antara kedua pihak yang bersengketa dalam bentuk perjanjian yang ditandatangani oleh para pihak yang bersengketa yang dapat dilakukan sebelum maupun setelah terjadinya sengketa. Karena alasan ini, perjanjian secara tertulis harus dilakukan oleh kedua pihak sebelum arbitrase. Di Indonesia terdapat beberapa badan khusus yang memfasilitasi proses arbitrase, yaitu Badan Arbitrase Nasional Indonesia (BANI). (Helmi Kasim, 2018 : 84)

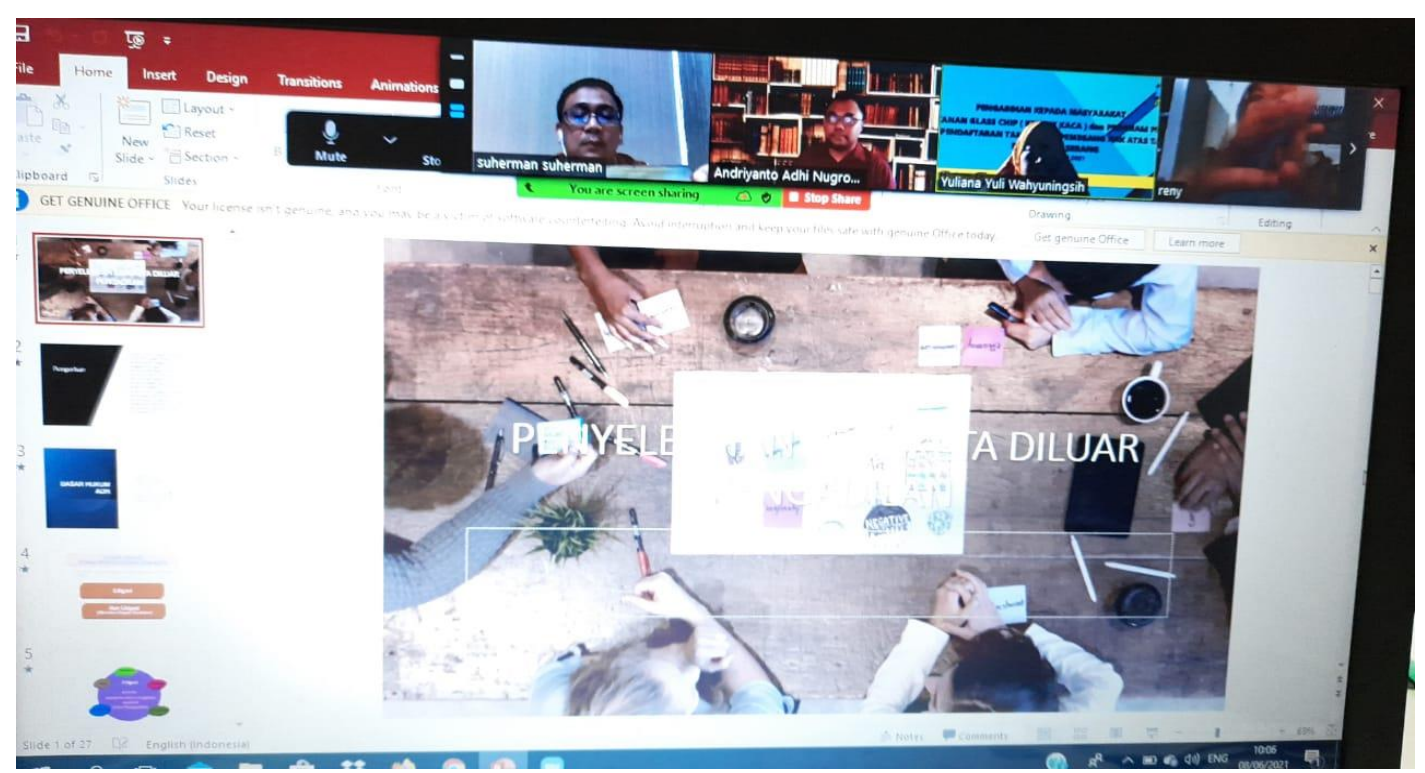

Gambar 2. Pelaksanaan presentasi menggunakan zoom cloud meeting.

Pada acara diskusi dan tanya jawab, para peserta sangat antasius untuk berdiskusi dan bertanya kepada tim pengabdi. Pertanyaan yang ditanyakan oleh peserta terkait dengan:

a. Apakah perangkat desa bisa menjadi pihak ketiga seperti mediator dalam membantu sengketa antar warga di desa Baros.

b. Bagaimana langkah selanjutnya jika dalam mendamaikan warga dengan mediasi itu berhasil dan bagaimana juga jika tidak berhasil

c. Apakah ADR ini sifatnya sukarela. 
d. Apabila jika warga yang bersengketa melalui jalur konsultasi maka apa saja yang harus disiapkan oleh warga

e. Apakah perbedaan antara konsultasi dengan negosiasi.
Pada acara diskusi ini juga pengabdi mendapatkan data-data terkait warga desa Baros terkait dengan :

Tabel 1. Data Desa Baros

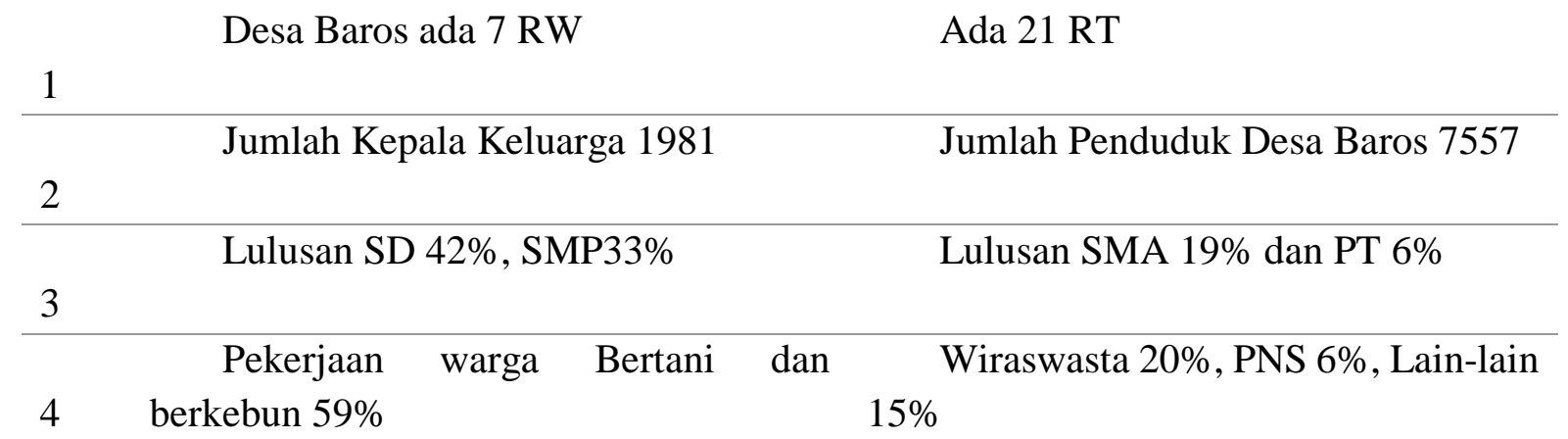

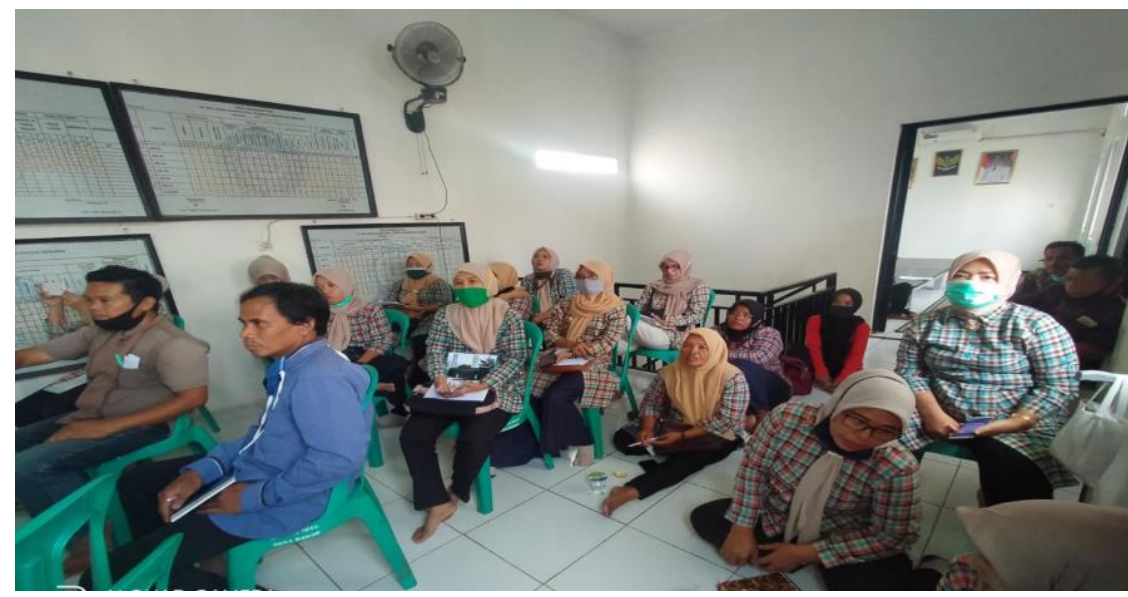

Gambar 3. Pelaksanaan diskusi dan tanya jawab peserta pengabdian masyarakat

Dengan adanya pendampingan dan sosialisasi tentang “ Bantuan Hukum Online Nonlitigasi Dalam Rangka Menuju Desa Yang Modern dan Berkeadilan”, ini maka diharapkan adanya keadilan bagi warga desa Baros yang sedang menyelesaikan sengketanya dan agar lebih cepat penyelesaian sengketa yang dihadapinya. Disamping itu dengan sosialisasi ini juga diharapkan desa Baros menjadi desa yang modern yang dapat menggunakan dan memanfaatkan kemajuan teknologi yang modern saat ini.

\section{PENUTUP}

Pelaksanaan pengabdian masyarakat di desa Baros berjalan baik dan lancar, hal ini karena kerjasama yang baik antara tim pengabdi dan kepala desa serta aparatnya juga kepada masyarakat Baros, maka dengan ini tim pengabdi menyimpulkan bahwa pentingnya sosialisasi bagi masyarakat di daerah pedesaan terkait 
dengan bantuan hukum online nonlitigasi agar warga desa Baros mendapatkan keadilan dalam penyelesaian sengketa untuk perkara yang dihadapinya dan sosialisasi online ini juga akan memberikan manfaat bagi warga desa Baros untuk dapat memanfaatkan teknologi yang saat ini berkembang pesat agar menjadi desa yang modern. Walaupun pada saat ini penggunaan alat-alat teknologi seperi laptop, Hand phone android, computer dan internet di desa Baros masih sedikit warga yang memahami akan tetapi warga terus ingin belajar untuk menggunakan teknologi tersebut sehingga diharapkan kedepannya kantor desa dapat menyediakan jaringan internet dan komputer untuk warganya yang ingin belajar dalam penggunaan teknologi tersebut.

\section{DAFTAR PUSTAKA}

\section{Buku dan Jurnal}

Arinanto, Satya 2015. Hak Asasi Manusia dalam Transisi Politik Di Indonesia, Universitas Indonesia Fakultas Hukum

Ardillah Albar, Andi, 2019, Dinamika Mekanisme Alternatif Penyelesaian SengketaDalam Kontek Hukum Bisnis Internasional, Jurnal Hukum Kenotariatan, Vol 1, No. 1

Bachtiar, 2016, Jurnal Sosial \& Budaya Syar-i FSH UIN Syarif Hidayatullah, Jakarta Vol. 3 No. 2

Hahury, Hendri Dhony,etc, Strategi Penghidupan Rumah Tangga Pedesaan Dalam Menghadapi Dampak Pandemik Covid 19, Jurnal Pengabdian Pada Masyarakat, Vol. 6, No. 2

Imam Fauzi, Suyogi dan Puspita Ningtyas, 2018,
Optimalisasi
Pemberian Bantuan Hukum Demi terwujudnya assess to law and justice bagi rakyat miskin, Jurnal Konstitusi, Jakarta Vol 15, No. 1

Kasim, Helmi, 2018, Arbitrase sebagai Penyelesaian sengketa penanaman modal, Jurnal Recht Vinding, Vol. 7, No. 1

Nasution, Adnan Buyung dalam Abdurrahman, Aspek-Aspek Bantuan Hukum di Indonesia, Jakarta: Cendana Press

Rhode, Deborah L, 2004, Access to Justice, Oxford University Press, New York.

Syafrida, 2020, Alternative penyelesaian sengketa sebagai solusi mewujudkan asas pemeriksaan perkara sederhana, waktu singkat dan biaya murah, Jurnal Salam : Sosial \& Budaya Syar-I, Jakarta, Vol 7, No, 4 Sugianto, Fajar, etc, 2020, Idealisasi Sifat alternative dalam penyelesaian sengketa melalui mediasi, Jurnal Bonum Commune, Vol. 3, No. 2.

Sutiyoso, Bambang dan Puspitasari, Hastuti, 2005, Aspek-Aspek Perkembangan Kekuasaan Kehakiman di Indonesia, UII Press, Yogyakarta.

Varida Ariani, Nevey, 2012, Alternative Penyelesaian Sengketa Bisnis Diluar Pengadilan, Jurnal Recht Vinding, Vol 1, Nomor 2

\section{Peraturan Perundang-undangan}

Republik Indonesia, Undang-Undang Nomor 30 Tahun 1999 tentang

Arbitrase dan alternative

penyelesaian sengketa Undang-Undang Nomor

16 Tahun 2011 tentang Bantuan Hukum 